\title{
Seasonal variation of mesozooplankton biomass, abundance and copepod grazing in the central Cantabrian Sea (southern B ay of B iscay)
}

\author{
IÑAKI HUSKIN ${ }^{1,2}$, EVA LÓPEZ ${ }^{1}$, LETICIA VIESCA ${ }^{1}$ and RICARDO ANADÓN ${ }^{1}$ \\ ${ }^{1}$ University of Oviedo, Dpto. BOS, c/ Catedrático Rodrigo Uría, s/n, 33071 Oviedo, Spain. \\ ${ }^{2}$ Present Address: Instituto Español de Oceanografía, C. O. de Santander, Promontorio San Martín, s/n, 39004 Santander,
} Spain.E-mail: inaki@st.ieo.es

\begin{abstract}
SUMMARY: Size fractionated mesozooplankton biomass, abundance and copepod grazing were investigated over an annual cycle (1998) at two stations off Cudillero (central Cantabrian Sea). Mesozooplankton biomass was higher in summer/early autumn, reaching $\sim 3000 \mathrm{mg} \mathrm{dw} \mathrm{m}^{-2}$ in September. Copepods were the most abundant taxonomic group, representing 91 and $81 \%$ of the total mesozooplankton abundance in the coastal and shelf-break station respectively. Copepod gut contents were higher in summer at the coastal station, while the shelf-break station showed maximum gut contents in April. Gut contents were linearly related to integrated chlorophyll, except in the case of large animals at the shelf break station. Copepod community carbon ingestion was higher from June to September at both stations, reaching a maximum value of $\sim 165 \mathrm{mg} \mathrm{C} \mathrm{m}^{-2}$ day $^{-1}$. Calculated grazing rates translates into an average daily consumption values of $8.7 \%$ (coast) and 5.25\% (shelf-break) of total chlorophyll stock, or $20 \%$ (shelf-break) of total primary production.
\end{abstract}

Keywords: mesozooplankton, copepod, grazing, gut contents, Cantabrian Sea.

\begin{abstract}
RESUMEN: VARIACIÓN ESTACIONAL DE LA BIOMASA Y ABUNDANCIA DEL MESOZOOPLANCTON Y HERBIVORÍA DE COPÉPODOS EN el CANTÁbrico CEnTRAl (Sur del Golfo de VizCAYA). - A lo largo del año 1998, se estudió la biomasa y abundancia del mesozooplancton (en distintas fracciones de tamaño) así como la ingestión de la comunidad de copépodos en dos estaciones cercanas a Cudillero (Mar Cantábrico). La biomasa del mesozooplancton presentó sus valores más elevados en verano y a principios del otoño, alcanzando máximos de $3000 \mathrm{mg}$ Peso Seco $\mathrm{m}^{-2}$ en Septiembre. Los copépodos fueron el grupo taxonómico más abundante, representando el $91 \%$ y el $81 \%$ de la abundancia total del mesozooplancton en las estaciones de costa y talud respectivamente. El contenido estomacal de los copépodos en la estación costera fue más elevado durante el verano, mientras que en la estación situada sobre el talud, el contenido estomacal más elevado se encontró en el mes de Abril. Se encontró una relación lineal entre el contenido estomacal de los copépodos y el valor de clorofila integrado en la columna de agua, excepto en el caso de los copépodos grandes en la estación de talud. La ingestión de carbono de la comunidad de copépodos fue más elevada entre Junio y Septiembre en ambas estaciones, alcanzando valores máximos de $\sim 165 \mathrm{mg} \mathrm{C} \mathrm{m}^{-2}$ día $^{-1}$. La ingestión de la comunidad de copépodos representa un consumo diario del $8.7 \%$ (costa) y $5.25 \%$ (talud) de la clorofila total, y un $20 \%$ (talud) de la producción primaria total.
\end{abstract}

Palabras clave: mesozooplancton, copépodos, ingestión herbívora, contenido estomacal, Mar Cantábrico.

\section{INTRODUCTION}

One of the main challenges of oceanography is to improve the knowledge of the relationships between physical/biological characteristics of marine ecosystems and global change processes. In view of this, it is necessary to perform temporal studies that are extensive enough for a better understanding of the oceanic processes at a global scale. Seasonal studies in oceanography are especially important in regions where environmental conditions present a high degree of variation throughout 


\title{
Seasonal variation of mesozooplankton biomass, abundance and copepod grazing in the central Cantabrian Sea (southern B ay of B iscay)
}

\author{
IÑAKI HUSKIN ${ }^{1,2}$, EVA LÓPEZ ${ }^{1}$, LETICIA VIESCA ${ }^{1}$ and RICARDO ANADÓN ${ }^{1}$ \\ ${ }^{1}$ University of Oviedo, Dpto. BOS, c/ Catedrático Rodrigo Uría, s/n, 33071 Oviedo, Spain. \\ ${ }^{2}$ Present Address: Instituto Español de Oceanografía, C. O. de Santander, Promontorio San Martín, s/n, 39004 Santander,
} Spain.E-mail: inaki@st.ieo.es

\begin{abstract}
SUMMARY: Size fractionated mesozooplankton biomass, abundance and copepod grazing were investigated over an annual cycle (1998) at two stations off Cudillero (central Cantabrian Sea). Mesozooplankton biomass was higher in summer/early autumn, reaching $\sim 3000 \mathrm{mg} \mathrm{dw} \mathrm{m}^{-2}$ in September. Copepods were the most abundant taxonomic group, representing 91 and $81 \%$ of the total mesozooplankton abundance in the coastal and shelf-break station respectively. Copepod gut contents were higher in summer at the coastal station, while the shelf-break station showed maximum gut contents in April. Gut contents were linearly related to integrated chlorophyll, except in the case of large animals at the shelf break station. Copepod community carbon ingestion was higher from June to September at both stations, reaching a maximum value of $\sim 165 \mathrm{mg} \mathrm{C} \mathrm{m}^{-2}$ day $^{-1}$. Calculated grazing rates translates into an average daily consumption values of $8.7 \%$ (coast) and 5.25\% (shelf-break) of total chlorophyll stock, or $20 \%$ (shelf-break) of total primary production.
\end{abstract}

Keywords: mesozooplankton, copepod, grazing, gut contents, Cantabrian Sea.

\begin{abstract}
RESUMEN: VARIACIÓN ESTACIONAL DE LA BIOMASA Y ABUNDANCIA DEL MESOZOOPLANCTON Y HERBIVORÍA DE COPÉPODOS EN el CANTÁbrico CEnTRAl (Sur del Golfo de VizCAYA). - A lo largo del año 1998, se estudió la biomasa y abundancia del mesozooplancton (en distintas fracciones de tamaño) así como la ingestión de la comunidad de copépodos en dos estaciones cercanas a Cudillero (Mar Cantábrico). La biomasa del mesozooplancton presentó sus valores más elevados en verano y a principios del otoño, alcanzando máximos de $3000 \mathrm{mg}$ Peso Seco $\mathrm{m}^{-2}$ en Septiembre. Los copépodos fueron el grupo taxonómico más abundante, representando el $91 \%$ y el $81 \%$ de la abundancia total del mesozooplancton en las estaciones de costa y talud respectivamente. El contenido estomacal de los copépodos en la estación costera fue más elevado durante el verano, mientras que en la estación situada sobre el talud, el contenido estomacal más elevado se encontró en el mes de Abril. Se encontró una relación lineal entre el contenido estomacal de los copépodos y el valor de clorofila integrado en la columna de agua, excepto en el caso de los copépodos grandes en la estación de talud. La ingestión de carbono de la comunidad de copépodos fue más elevada entre Junio y Septiembre en ambas estaciones, alcanzando valores máximos de $\sim 165 \mathrm{mg} \mathrm{C} \mathrm{m}^{-2}$ día $^{-1}$. La ingestión de la comunidad de copépodos representa un consumo diario del $8.7 \%$ (costa) y $5.25 \%$ (talud) de la clorofila total, y un $20 \%$ (talud) de la producción primaria total.
\end{abstract}

Palabras clave: mesozooplancton, copépodos, ingestión herbívora, contenido estomacal, Mar Cantábrico.

\section{INTRODUCTION}

One of the main challenges of oceanography is to improve the knowledge of the relationships between physical/biological characteristics of marine ecosystems and global change processes. In view of this, it is necessary to perform temporal studies that are extensive enough for a better understanding of the oceanic processes at a global scale. Seasonal studies in oceanography are especially important in regions where environmental conditions present a high degree of variation throughout 


\title{
Seasonal variation of mesozooplankton biomass, abundance and copepod grazing in the central Cantabrian Sea (southern B ay of B iscay)
}

\author{
IÑAKI HUSKIN ${ }^{1,2}$, EVA LÓPEZ ${ }^{1}$, LETICIA VIESCA ${ }^{1}$ and RICARDO ANADÓN ${ }^{1}$ \\ ${ }^{1}$ University of Oviedo, Dpto. BOS, c/ Catedrático Rodrigo Uría, s/n, 33071 Oviedo, Spain. \\ ${ }^{2}$ Present Address: Instituto Español de Oceanografía, C. O. de Santander, Promontorio San Martín, s/n, 39004 Santander,
} Spain.E-mail: inaki@st.ieo.es

\begin{abstract}
SUMMARY: Size fractionated mesozooplankton biomass, abundance and copepod grazing were investigated over an annual cycle (1998) at two stations off Cudillero (central Cantabrian Sea). Mesozooplankton biomass was higher in summer/early autumn, reaching $\sim 3000 \mathrm{mg} \mathrm{dw} \mathrm{m}^{-2}$ in September. Copepods were the most abundant taxonomic group, representing 91 and $81 \%$ of the total mesozooplankton abundance in the coastal and shelf-break station respectively. Copepod gut contents were higher in summer at the coastal station, while the shelf-break station showed maximum gut contents in April. Gut contents were linearly related to integrated chlorophyll, except in the case of large animals at the shelf break station. Copepod community carbon ingestion was higher from June to September at both stations, reaching a maximum value of $\sim 165 \mathrm{mg} \mathrm{C} \mathrm{m}^{-2}$ day $^{-1}$. Calculated grazing rates translates into an average daily consumption values of $8.7 \%$ (coast) and 5.25\% (shelf-break) of total chlorophyll stock, or $20 \%$ (shelf-break) of total primary production.
\end{abstract}

Keywords: mesozooplankton, copepod, grazing, gut contents, Cantabrian Sea.

\begin{abstract}
RESUMEN: VARIACIÓN ESTACIONAL DE LA BIOMASA Y ABUNDANCIA DEL MESOZOOPLANCTON Y HERBIVORÍA DE COPÉPODOS EN el CANTÁbrico CEnTRAl (Sur del Golfo de VizCAYA). - A lo largo del año 1998, se estudió la biomasa y abundancia del mesozooplancton (en distintas fracciones de tamaño) así como la ingestión de la comunidad de copépodos en dos estaciones cercanas a Cudillero (Mar Cantábrico). La biomasa del mesozooplancton presentó sus valores más elevados en verano y a principios del otoño, alcanzando máximos de $3000 \mathrm{mg}$ Peso Seco $\mathrm{m}^{-2}$ en Septiembre. Los copépodos fueron el grupo taxonómico más abundante, representando el $91 \%$ y el $81 \%$ de la abundancia total del mesozooplancton en las estaciones de costa y talud respectivamente. El contenido estomacal de los copépodos en la estación costera fue más elevado durante el verano, mientras que en la estación situada sobre el talud, el contenido estomacal más elevado se encontró en el mes de Abril. Se encontró una relación lineal entre el contenido estomacal de los copépodos y el valor de clorofila integrado en la columna de agua, excepto en el caso de los copépodos grandes en la estación de talud. La ingestión de carbono de la comunidad de copépodos fue más elevada entre Junio y Septiembre en ambas estaciones, alcanzando valores máximos de $\sim 165 \mathrm{mg} \mathrm{C} \mathrm{m}^{-2}$ día $^{-1}$. La ingestión de la comunidad de copépodos representa un consumo diario del $8.7 \%$ (costa) y $5.25 \%$ (talud) de la clorofila total, y un $20 \%$ (talud) de la producción primaria total.
\end{abstract}

Palabras clave: mesozooplancton, copépodos, ingestión herbívora, contenido estomacal, Mar Cantábrico.

\section{INTRODUCTION}

One of the main challenges of oceanography is to improve the knowledge of the relationships between physical/biological characteristics of marine ecosystems and global change processes. In view of this, it is necessary to perform temporal studies that are extensive enough for a better understanding of the oceanic processes at a global scale. Seasonal studies in oceanography are especially important in regions where environmental conditions present a high degree of variation throughout 


\title{
Seasonal variation of mesozooplankton biomass, abundance and copepod grazing in the central Cantabrian Sea (southern B ay of B iscay)
}

\author{
IÑAKI HUSKIN ${ }^{1,2}$, EVA LÓPEZ ${ }^{1}$, LETICIA VIESCA ${ }^{1}$ and RICARDO ANADÓN ${ }^{1}$ \\ ${ }^{1}$ University of Oviedo, Dpto. BOS, c/ Catedrático Rodrigo Uría, s/n, 33071 Oviedo, Spain. \\ ${ }^{2}$ Present Address: Instituto Español de Oceanografía, C. O. de Santander, Promontorio San Martín, s/n, 39004 Santander,
} Spain.E-mail: inaki@st.ieo.es

\begin{abstract}
SUMMARY: Size fractionated mesozooplankton biomass, abundance and copepod grazing were investigated over an annual cycle (1998) at two stations off Cudillero (central Cantabrian Sea). Mesozooplankton biomass was higher in summer/early autumn, reaching $\sim 3000 \mathrm{mg} \mathrm{dw} \mathrm{m}^{-2}$ in September. Copepods were the most abundant taxonomic group, representing 91 and $81 \%$ of the total mesozooplankton abundance in the coastal and shelf-break station respectively. Copepod gut contents were higher in summer at the coastal station, while the shelf-break station showed maximum gut contents in April. Gut contents were linearly related to integrated chlorophyll, except in the case of large animals at the shelf break station. Copepod community carbon ingestion was higher from June to September at both stations, reaching a maximum value of $\sim 165 \mathrm{mg} \mathrm{C} \mathrm{m}^{-2}$ day $^{-1}$. Calculated grazing rates translates into an average daily consumption values of $8.7 \%$ (coast) and 5.25\% (shelf-break) of total chlorophyll stock, or $20 \%$ (shelf-break) of total primary production.
\end{abstract}

Keywords: mesozooplankton, copepod, grazing, gut contents, Cantabrian Sea.

\begin{abstract}
RESUMEN: VARIACIÓN ESTACIONAL DE LA BIOMASA Y ABUNDANCIA DEL MESOZOOPLANCTON Y HERBIVORÍA DE COPÉPODOS EN el CANTÁbrico CEnTRAl (Sur del Golfo de VizCAYA). - A lo largo del año 1998, se estudió la biomasa y abundancia del mesozooplancton (en distintas fracciones de tamaño) así como la ingestión de la comunidad de copépodos en dos estaciones cercanas a Cudillero (Mar Cantábrico). La biomasa del mesozooplancton presentó sus valores más elevados en verano y a principios del otoño, alcanzando máximos de $3000 \mathrm{mg}$ Peso Seco $\mathrm{m}^{-2}$ en Septiembre. Los copépodos fueron el grupo taxonómico más abundante, representando el $91 \%$ y el $81 \%$ de la abundancia total del mesozooplancton en las estaciones de costa y talud respectivamente. El contenido estomacal de los copépodos en la estación costera fue más elevado durante el verano, mientras que en la estación situada sobre el talud, el contenido estomacal más elevado se encontró en el mes de Abril. Se encontró una relación lineal entre el contenido estomacal de los copépodos y el valor de clorofila integrado en la columna de agua, excepto en el caso de los copépodos grandes en la estación de talud. La ingestión de carbono de la comunidad de copépodos fue más elevada entre Junio y Septiembre en ambas estaciones, alcanzando valores máximos de $\sim 165 \mathrm{mg} \mathrm{C} \mathrm{m}^{-2}$ día $^{-1}$. La ingestión de la comunidad de copépodos representa un consumo diario del $8.7 \%$ (costa) y $5.25 \%$ (talud) de la clorofila total, y un $20 \%$ (talud) de la producción primaria total.
\end{abstract}

Palabras clave: mesozooplancton, copépodos, ingestión herbívora, contenido estomacal, Mar Cantábrico.

\section{INTRODUCTION}

One of the main challenges of oceanography is to improve the knowledge of the relationships between physical/biological characteristics of marine ecosystems and global change processes. In view of this, it is necessary to perform temporal studies that are extensive enough for a better understanding of the oceanic processes at a global scale. Seasonal studies in oceanography are especially important in regions where environmental conditions present a high degree of variation throughout 


\title{
Seasonal variation of mesozooplankton biomass, abundance and copepod grazing in the central Cantabrian Sea (southern B ay of B iscay)
}

\author{
IÑAKI HUSKIN ${ }^{1,2}$, EVA LÓPEZ ${ }^{1}$, LETICIA VIESCA ${ }^{1}$ and RICARDO ANADÓN ${ }^{1}$ \\ ${ }^{1}$ University of Oviedo, Dpto. BOS, c/ Catedrático Rodrigo Uría, s/n, 33071 Oviedo, Spain. \\ ${ }^{2}$ Present Address: Instituto Español de Oceanografía, C. O. de Santander, Promontorio San Martín, s/n, 39004 Santander,
} Spain.E-mail: inaki@st.ieo.es

\begin{abstract}
SUMMARY: Size fractionated mesozooplankton biomass, abundance and copepod grazing were investigated over an annual cycle (1998) at two stations off Cudillero (central Cantabrian Sea). Mesozooplankton biomass was higher in summer/early autumn, reaching $\sim 3000 \mathrm{mg} \mathrm{dw} \mathrm{m}^{-2}$ in September. Copepods were the most abundant taxonomic group, representing 91 and $81 \%$ of the total mesozooplankton abundance in the coastal and shelf-break station respectively. Copepod gut contents were higher in summer at the coastal station, while the shelf-break station showed maximum gut contents in April. Gut contents were linearly related to integrated chlorophyll, except in the case of large animals at the shelf break station. Copepod community carbon ingestion was higher from June to September at both stations, reaching a maximum value of $\sim 165 \mathrm{mg} \mathrm{C} \mathrm{m}^{-2}$ day $^{-1}$. Calculated grazing rates translates into an average daily consumption values of $8.7 \%$ (coast) and 5.25\% (shelf-break) of total chlorophyll stock, or $20 \%$ (shelf-break) of total primary production.
\end{abstract}

Keywords: mesozooplankton, copepod, grazing, gut contents, Cantabrian Sea.

\begin{abstract}
RESUMEN: VARIACIÓN ESTACIONAL DE LA BIOMASA Y ABUNDANCIA DEL MESOZOOPLANCTON Y HERBIVORÍA DE COPÉPODOS EN el CANTÁbrico CEnTRAl (Sur del Golfo de VizCAYA). - A lo largo del año 1998, se estudió la biomasa y abundancia del mesozooplancton (en distintas fracciones de tamaño) así como la ingestión de la comunidad de copépodos en dos estaciones cercanas a Cudillero (Mar Cantábrico). La biomasa del mesozooplancton presentó sus valores más elevados en verano y a principios del otoño, alcanzando máximos de $3000 \mathrm{mg}$ Peso Seco $\mathrm{m}^{-2}$ en Septiembre. Los copépodos fueron el grupo taxonómico más abundante, representando el $91 \%$ y el $81 \%$ de la abundancia total del mesozooplancton en las estaciones de costa y talud respectivamente. El contenido estomacal de los copépodos en la estación costera fue más elevado durante el verano, mientras que en la estación situada sobre el talud, el contenido estomacal más elevado se encontró en el mes de Abril. Se encontró una relación lineal entre el contenido estomacal de los copépodos y el valor de clorofila integrado en la columna de agua, excepto en el caso de los copépodos grandes en la estación de talud. La ingestión de carbono de la comunidad de copépodos fue más elevada entre Junio y Septiembre en ambas estaciones, alcanzando valores máximos de $\sim 165 \mathrm{mg} \mathrm{C} \mathrm{m}^{-2}$ día $^{-1}$. La ingestión de la comunidad de copépodos representa un consumo diario del $8.7 \%$ (costa) y $5.25 \%$ (talud) de la clorofila total, y un $20 \%$ (talud) de la producción primaria total.
\end{abstract}

Palabras clave: mesozooplancton, copépodos, ingestión herbívora, contenido estomacal, Mar Cantábrico.

\section{INTRODUCTION}

One of the main challenges of oceanography is to improve the knowledge of the relationships between physical/biological characteristics of marine ecosystems and global change processes. In view of this, it is necessary to perform temporal studies that are extensive enough for a better understanding of the oceanic processes at a global scale. Seasonal studies in oceanography are especially important in regions where environmental conditions present a high degree of variation throughout 


\title{
Seasonal variation of mesozooplankton biomass, abundance and copepod grazing in the central Cantabrian Sea (southern B ay of B iscay)
}

\author{
IÑAKI HUSKIN ${ }^{1,2}$, EVA LÓPEZ ${ }^{1}$, LETICIA VIESCA ${ }^{1}$ and RICARDO ANADÓN ${ }^{1}$ \\ ${ }^{1}$ University of Oviedo, Dpto. BOS, c/ Catedrático Rodrigo Uría, s/n, 33071 Oviedo, Spain. \\ ${ }^{2}$ Present Address: Instituto Español de Oceanografía, C. O. de Santander, Promontorio San Martín, s/n, 39004 Santander,
} Spain.E-mail: inaki@st.ieo.es

\begin{abstract}
SUMMARY: Size fractionated mesozooplankton biomass, abundance and copepod grazing were investigated over an annual cycle (1998) at two stations off Cudillero (central Cantabrian Sea). Mesozooplankton biomass was higher in summer/early autumn, reaching $\sim 3000 \mathrm{mg} \mathrm{dw} \mathrm{m}^{-2}$ in September. Copepods were the most abundant taxonomic group, representing 91 and $81 \%$ of the total mesozooplankton abundance in the coastal and shelf-break station respectively. Copepod gut contents were higher in summer at the coastal station, while the shelf-break station showed maximum gut contents in April. Gut contents were linearly related to integrated chlorophyll, except in the case of large animals at the shelf break station. Copepod community carbon ingestion was higher from June to September at both stations, reaching a maximum value of $\sim 165 \mathrm{mg} \mathrm{C} \mathrm{m}^{-2}$ day $^{-1}$. Calculated grazing rates translates into an average daily consumption values of $8.7 \%$ (coast) and 5.25\% (shelf-break) of total chlorophyll stock, or $20 \%$ (shelf-break) of total primary production.
\end{abstract}

Keywords: mesozooplankton, copepod, grazing, gut contents, Cantabrian Sea.

\begin{abstract}
RESUMEN: VARIACIÓN ESTACIONAL DE LA BIOMASA Y ABUNDANCIA DEL MESOZOOPLANCTON Y HERBIVORÍA DE COPÉPODOS EN el CANTÁbrico CEnTRAl (Sur del Golfo de VizCAYA). - A lo largo del año 1998, se estudió la biomasa y abundancia del mesozooplancton (en distintas fracciones de tamaño) así como la ingestión de la comunidad de copépodos en dos estaciones cercanas a Cudillero (Mar Cantábrico). La biomasa del mesozooplancton presentó sus valores más elevados en verano y a principios del otoño, alcanzando máximos de $3000 \mathrm{mg}$ Peso Seco $\mathrm{m}^{-2}$ en Septiembre. Los copépodos fueron el grupo taxonómico más abundante, representando el $91 \%$ y el $81 \%$ de la abundancia total del mesozooplancton en las estaciones de costa y talud respectivamente. El contenido estomacal de los copépodos en la estación costera fue más elevado durante el verano, mientras que en la estación situada sobre el talud, el contenido estomacal más elevado se encontró en el mes de Abril. Se encontró una relación lineal entre el contenido estomacal de los copépodos y el valor de clorofila integrado en la columna de agua, excepto en el caso de los copépodos grandes en la estación de talud. La ingestión de carbono de la comunidad de copépodos fue más elevada entre Junio y Septiembre en ambas estaciones, alcanzando valores máximos de $\sim 165 \mathrm{mg} \mathrm{C} \mathrm{m}^{-2}$ día $^{-1}$. La ingestión de la comunidad de copépodos representa un consumo diario del $8.7 \%$ (costa) y $5.25 \%$ (talud) de la clorofila total, y un $20 \%$ (talud) de la producción primaria total.
\end{abstract}

Palabras clave: mesozooplancton, copépodos, ingestión herbívora, contenido estomacal, Mar Cantábrico.

\section{INTRODUCTION}

One of the main challenges of oceanography is to improve the knowledge of the relationships between physical/biological characteristics of marine ecosystems and global change processes. In view of this, it is necessary to perform temporal studies that are extensive enough for a better understanding of the oceanic processes at a global scale. Seasonal studies in oceanography are especially important in regions where environmental conditions present a high degree of variation throughout 


\title{
Seasonal variation of mesozooplankton biomass, abundance and copepod grazing in the central Cantabrian Sea (southern B ay of B iscay)
}

\author{
IÑAKI HUSKIN ${ }^{1,2}$, EVA LÓPEZ ${ }^{1}$, LETICIA VIESCA ${ }^{1}$ and RICARDO ANADÓN ${ }^{1}$ \\ ${ }^{1}$ University of Oviedo, Dpto. BOS, c/ Catedrático Rodrigo Uría, s/n, 33071 Oviedo, Spain. \\ ${ }^{2}$ Present Address: Instituto Español de Oceanografía, C. O. de Santander, Promontorio San Martín, s/n, 39004 Santander,
} Spain.E-mail: inaki@st.ieo.es

\begin{abstract}
SUMMARY: Size fractionated mesozooplankton biomass, abundance and copepod grazing were investigated over an annual cycle (1998) at two stations off Cudillero (central Cantabrian Sea). Mesozooplankton biomass was higher in summer/early autumn, reaching $\sim 3000 \mathrm{mg} \mathrm{dw} \mathrm{m}^{-2}$ in September. Copepods were the most abundant taxonomic group, representing 91 and $81 \%$ of the total mesozooplankton abundance in the coastal and shelf-break station respectively. Copepod gut contents were higher in summer at the coastal station, while the shelf-break station showed maximum gut contents in April. Gut contents were linearly related to integrated chlorophyll, except in the case of large animals at the shelf break station. Copepod community carbon ingestion was higher from June to September at both stations, reaching a maximum value of $\sim 165 \mathrm{mg} \mathrm{C} \mathrm{m}^{-2}$ day $^{-1}$. Calculated grazing rates translates into an average daily consumption values of $8.7 \%$ (coast) and 5.25\% (shelf-break) of total chlorophyll stock, or $20 \%$ (shelf-break) of total primary production.
\end{abstract}

Keywords: mesozooplankton, copepod, grazing, gut contents, Cantabrian Sea.

\begin{abstract}
RESUMEN: VARIACIÓN ESTACIONAL DE LA BIOMASA Y ABUNDANCIA DEL MESOZOOPLANCTON Y HERBIVORÍA DE COPÉPODOS EN el CANTÁbrico CEnTRAl (Sur del Golfo de VizCAYA). - A lo largo del año 1998, se estudió la biomasa y abundancia del mesozooplancton (en distintas fracciones de tamaño) así como la ingestión de la comunidad de copépodos en dos estaciones cercanas a Cudillero (Mar Cantábrico). La biomasa del mesozooplancton presentó sus valores más elevados en verano y a principios del otoño, alcanzando máximos de $3000 \mathrm{mg}$ Peso Seco $\mathrm{m}^{-2}$ en Septiembre. Los copépodos fueron el grupo taxonómico más abundante, representando el $91 \%$ y el $81 \%$ de la abundancia total del mesozooplancton en las estaciones de costa y talud respectivamente. El contenido estomacal de los copépodos en la estación costera fue más elevado durante el verano, mientras que en la estación situada sobre el talud, el contenido estomacal más elevado se encontró en el mes de Abril. Se encontró una relación lineal entre el contenido estomacal de los copépodos y el valor de clorofila integrado en la columna de agua, excepto en el caso de los copépodos grandes en la estación de talud. La ingestión de carbono de la comunidad de copépodos fue más elevada entre Junio y Septiembre en ambas estaciones, alcanzando valores máximos de $\sim 165 \mathrm{mg} \mathrm{C} \mathrm{m}^{-2}$ día $^{-1}$. La ingestión de la comunidad de copépodos representa un consumo diario del $8.7 \%$ (costa) y $5.25 \%$ (talud) de la clorofila total, y un $20 \%$ (talud) de la producción primaria total.
\end{abstract}

Palabras clave: mesozooplancton, copépodos, ingestión herbívora, contenido estomacal, Mar Cantábrico.

\section{INTRODUCTION}

One of the main challenges of oceanography is to improve the knowledge of the relationships between physical/biological characteristics of marine ecosystems and global change processes. In view of this, it is necessary to perform temporal studies that are extensive enough for a better understanding of the oceanic processes at a global scale. Seasonal studies in oceanography are especially important in regions where environmental conditions present a high degree of variation throughout 


\title{
Seasonal variation of mesozooplankton biomass, abundance and copepod grazing in the central Cantabrian Sea (southern B ay of B iscay)
}

\author{
IÑAKI HUSKIN ${ }^{1,2}$, EVA LÓPEZ ${ }^{1}$, LETICIA VIESCA ${ }^{1}$ and RICARDO ANADÓN ${ }^{1}$ \\ ${ }^{1}$ University of Oviedo, Dpto. BOS, c/ Catedrático Rodrigo Uría, s/n, 33071 Oviedo, Spain. \\ ${ }^{2}$ Present Address: Instituto Español de Oceanografía, C. O. de Santander, Promontorio San Martín, s/n, 39004 Santander,
} Spain.E-mail: inaki@st.ieo.es

\begin{abstract}
SUMMARY: Size fractionated mesozooplankton biomass, abundance and copepod grazing were investigated over an annual cycle (1998) at two stations off Cudillero (central Cantabrian Sea). Mesozooplankton biomass was higher in summer/early autumn, reaching $\sim 3000 \mathrm{mg} \mathrm{dw} \mathrm{m}^{-2}$ in September. Copepods were the most abundant taxonomic group, representing 91 and $81 \%$ of the total mesozooplankton abundance in the coastal and shelf-break station respectively. Copepod gut contents were higher in summer at the coastal station, while the shelf-break station showed maximum gut contents in April. Gut contents were linearly related to integrated chlorophyll, except in the case of large animals at the shelf break station. Copepod community carbon ingestion was higher from June to September at both stations, reaching a maximum value of $\sim 165 \mathrm{mg} \mathrm{C} \mathrm{m}^{-2}$ day $^{-1}$. Calculated grazing rates translates into an average daily consumption values of $8.7 \%$ (coast) and 5.25\% (shelf-break) of total chlorophyll stock, or $20 \%$ (shelf-break) of total primary production.
\end{abstract}

Keywords: mesozooplankton, copepod, grazing, gut contents, Cantabrian Sea.

\begin{abstract}
RESUMEN: VARIACIÓN ESTACIONAL DE LA BIOMASA Y ABUNDANCIA DEL MESOZOOPLANCTON Y HERBIVORÍA DE COPÉPODOS EN el CANTÁbrico CEnTRAl (Sur del Golfo de VizCAYA). - A lo largo del año 1998, se estudió la biomasa y abundancia del mesozooplancton (en distintas fracciones de tamaño) así como la ingestión de la comunidad de copépodos en dos estaciones cercanas a Cudillero (Mar Cantábrico). La biomasa del mesozooplancton presentó sus valores más elevados en verano y a principios del otoño, alcanzando máximos de $3000 \mathrm{mg}$ Peso Seco $\mathrm{m}^{-2}$ en Septiembre. Los copépodos fueron el grupo taxonómico más abundante, representando el $91 \%$ y el $81 \%$ de la abundancia total del mesozooplancton en las estaciones de costa y talud respectivamente. El contenido estomacal de los copépodos en la estación costera fue más elevado durante el verano, mientras que en la estación situada sobre el talud, el contenido estomacal más elevado se encontró en el mes de Abril. Se encontró una relación lineal entre el contenido estomacal de los copépodos y el valor de clorofila integrado en la columna de agua, excepto en el caso de los copépodos grandes en la estación de talud. La ingestión de carbono de la comunidad de copépodos fue más elevada entre Junio y Septiembre en ambas estaciones, alcanzando valores máximos de $\sim 165 \mathrm{mg} \mathrm{C} \mathrm{m}^{-2}$ día $^{-1}$. La ingestión de la comunidad de copépodos representa un consumo diario del $8.7 \%$ (costa) y $5.25 \%$ (talud) de la clorofila total, y un $20 \%$ (talud) de la producción primaria total.
\end{abstract}

Palabras clave: mesozooplancton, copépodos, ingestión herbívora, contenido estomacal, Mar Cantábrico.

\section{INTRODUCTION}

One of the main challenges of oceanography is to improve the knowledge of the relationships between physical/biological characteristics of marine ecosystems and global change processes. In view of this, it is necessary to perform temporal studies that are extensive enough for a better understanding of the oceanic processes at a global scale. Seasonal studies in oceanography are especially important in regions where environmental conditions present a high degree of variation throughout 


\title{
Seasonal variation of mesozooplankton biomass, abundance and copepod grazing in the central Cantabrian Sea (southern B ay of B iscay)
}

\author{
IÑAKI HUSKIN ${ }^{1,2}$, EVA LÓPEZ ${ }^{1}$, LETICIA VIESCA ${ }^{1}$ and RICARDO ANADÓN ${ }^{1}$ \\ ${ }^{1}$ University of Oviedo, Dpto. BOS, c/ Catedrático Rodrigo Uría, s/n, 33071 Oviedo, Spain. \\ ${ }^{2}$ Present Address: Instituto Español de Oceanografía, C. O. de Santander, Promontorio San Martín, s/n, 39004 Santander,
} Spain.E-mail: inaki@st.ieo.es

\begin{abstract}
SUMMARY: Size fractionated mesozooplankton biomass, abundance and copepod grazing were investigated over an annual cycle (1998) at two stations off Cudillero (central Cantabrian Sea). Mesozooplankton biomass was higher in summer/early autumn, reaching $\sim 3000 \mathrm{mg} \mathrm{dw} \mathrm{m}^{-2}$ in September. Copepods were the most abundant taxonomic group, representing 91 and $81 \%$ of the total mesozooplankton abundance in the coastal and shelf-break station respectively. Copepod gut contents were higher in summer at the coastal station, while the shelf-break station showed maximum gut contents in April. Gut contents were linearly related to integrated chlorophyll, except in the case of large animals at the shelf break station. Copepod community carbon ingestion was higher from June to September at both stations, reaching a maximum value of $\sim 165 \mathrm{mg} \mathrm{C} \mathrm{m}^{-2}$ day $^{-1}$. Calculated grazing rates translates into an average daily consumption values of $8.7 \%$ (coast) and 5.25\% (shelf-break) of total chlorophyll stock, or $20 \%$ (shelf-break) of total primary production.
\end{abstract}

Keywords: mesozooplankton, copepod, grazing, gut contents, Cantabrian Sea.

\begin{abstract}
RESUMEN: VARIACIÓN ESTACIONAL DE LA BIOMASA Y ABUNDANCIA DEL MESOZOOPLANCTON Y HERBIVORÍA DE COPÉPODOS EN el CANTÁbrico CEnTRAl (Sur del Golfo de VizCAYA). - A lo largo del año 1998, se estudió la biomasa y abundancia del mesozooplancton (en distintas fracciones de tamaño) así como la ingestión de la comunidad de copépodos en dos estaciones cercanas a Cudillero (Mar Cantábrico). La biomasa del mesozooplancton presentó sus valores más elevados en verano y a principios del otoño, alcanzando máximos de $3000 \mathrm{mg}$ Peso Seco $\mathrm{m}^{-2}$ en Septiembre. Los copépodos fueron el grupo taxonómico más abundante, representando el $91 \%$ y el $81 \%$ de la abundancia total del mesozooplancton en las estaciones de costa y talud respectivamente. El contenido estomacal de los copépodos en la estación costera fue más elevado durante el verano, mientras que en la estación situada sobre el talud, el contenido estomacal más elevado se encontró en el mes de Abril. Se encontró una relación lineal entre el contenido estomacal de los copépodos y el valor de clorofila integrado en la columna de agua, excepto en el caso de los copépodos grandes en la estación de talud. La ingestión de carbono de la comunidad de copépodos fue más elevada entre Junio y Septiembre en ambas estaciones, alcanzando valores máximos de $\sim 165 \mathrm{mg} \mathrm{C} \mathrm{m}^{-2}$ día $^{-1}$. La ingestión de la comunidad de copépodos representa un consumo diario del $8.7 \%$ (costa) y $5.25 \%$ (talud) de la clorofila total, y un $20 \%$ (talud) de la producción primaria total.
\end{abstract}

Palabras clave: mesozooplancton, copépodos, ingestión herbívora, contenido estomacal, Mar Cantábrico.

\section{INTRODUCTION}

One of the main challenges of oceanography is to improve the knowledge of the relationships between physical/biological characteristics of marine ecosystems and global change processes. In view of this, it is necessary to perform temporal studies that are extensive enough for a better understanding of the oceanic processes at a global scale. Seasonal studies in oceanography are especially important in regions where environmental conditions present a high degree of variation throughout 


\title{
Seasonal variation of mesozooplankton biomass, abundance and copepod grazing in the central Cantabrian Sea (southern B ay of B iscay)
}

\author{
IÑAKI HUSKIN ${ }^{1,2}$, EVA LÓPEZ ${ }^{1}$, LETICIA VIESCA ${ }^{1}$ and RICARDO ANADÓN ${ }^{1}$ \\ ${ }^{1}$ University of Oviedo, Dpto. BOS, c/ Catedrático Rodrigo Uría, s/n, 33071 Oviedo, Spain. \\ ${ }^{2}$ Present Address: Instituto Español de Oceanografía, C. O. de Santander, Promontorio San Martín, s/n, 39004 Santander,
} Spain.E-mail: inaki@st.ieo.es

\begin{abstract}
SUMMARY: Size fractionated mesozooplankton biomass, abundance and copepod grazing were investigated over an annual cycle (1998) at two stations off Cudillero (central Cantabrian Sea). Mesozooplankton biomass was higher in summer/early autumn, reaching $\sim 3000 \mathrm{mg} \mathrm{dw} \mathrm{m}^{-2}$ in September. Copepods were the most abundant taxonomic group, representing 91 and $81 \%$ of the total mesozooplankton abundance in the coastal and shelf-break station respectively. Copepod gut contents were higher in summer at the coastal station, while the shelf-break station showed maximum gut contents in April. Gut contents were linearly related to integrated chlorophyll, except in the case of large animals at the shelf break station. Copepod community carbon ingestion was higher from June to September at both stations, reaching a maximum value of $\sim 165 \mathrm{mg} \mathrm{C} \mathrm{m}^{-2}$ day $^{-1}$. Calculated grazing rates translates into an average daily consumption values of $8.7 \%$ (coast) and 5.25\% (shelf-break) of total chlorophyll stock, or $20 \%$ (shelf-break) of total primary production.
\end{abstract}

Keywords: mesozooplankton, copepod, grazing, gut contents, Cantabrian Sea.

\begin{abstract}
RESUMEN: VARIACIÓN ESTACIONAL DE LA BIOMASA Y ABUNDANCIA DEL MESOZOOPLANCTON Y HERBIVORÍA DE COPÉPODOS EN el CANTÁbrico CEnTRAl (Sur del Golfo de VizCAYA). - A lo largo del año 1998, se estudió la biomasa y abundancia del mesozooplancton (en distintas fracciones de tamaño) así como la ingestión de la comunidad de copépodos en dos estaciones cercanas a Cudillero (Mar Cantábrico). La biomasa del mesozooplancton presentó sus valores más elevados en verano y a principios del otoño, alcanzando máximos de $3000 \mathrm{mg}$ Peso Seco $\mathrm{m}^{-2}$ en Septiembre. Los copépodos fueron el grupo taxonómico más abundante, representando el $91 \%$ y el $81 \%$ de la abundancia total del mesozooplancton en las estaciones de costa y talud respectivamente. El contenido estomacal de los copépodos en la estación costera fue más elevado durante el verano, mientras que en la estación situada sobre el talud, el contenido estomacal más elevado se encontró en el mes de Abril. Se encontró una relación lineal entre el contenido estomacal de los copépodos y el valor de clorofila integrado en la columna de agua, excepto en el caso de los copépodos grandes en la estación de talud. La ingestión de carbono de la comunidad de copépodos fue más elevada entre Junio y Septiembre en ambas estaciones, alcanzando valores máximos de $\sim 165 \mathrm{mg} \mathrm{C} \mathrm{m}^{-2}$ día $^{-1}$. La ingestión de la comunidad de copépodos representa un consumo diario del $8.7 \%$ (costa) y $5.25 \%$ (talud) de la clorofila total, y un $20 \%$ (talud) de la producción primaria total.
\end{abstract}

Palabras clave: mesozooplancton, copépodos, ingestión herbívora, contenido estomacal, Mar Cantábrico.

\section{INTRODUCTION}

One of the main challenges of oceanography is to improve the knowledge of the relationships between physical/biological characteristics of marine ecosystems and global change processes. In view of this, it is necessary to perform temporal studies that are extensive enough for a better understanding of the oceanic processes at a global scale. Seasonal studies in oceanography are especially important in regions where environmental conditions present a high degree of variation throughout 


\title{
Seasonal variation of mesozooplankton biomass, abundance and copepod grazing in the central Cantabrian Sea (southern B ay of B iscay)
}

\author{
IÑAKI HUSKIN ${ }^{1,2}$, EVA LÓPEZ ${ }^{1}$, LETICIA VIESCA ${ }^{1}$ and RICARDO ANADÓN ${ }^{1}$ \\ ${ }^{1}$ University of Oviedo, Dpto. BOS, c/ Catedrático Rodrigo Uría, s/n, 33071 Oviedo, Spain. \\ ${ }^{2}$ Present Address: Instituto Español de Oceanografía, C. O. de Santander, Promontorio San Martín, s/n, 39004 Santander,
} Spain.E-mail: inaki@st.ieo.es

\begin{abstract}
SUMMARY: Size fractionated mesozooplankton biomass, abundance and copepod grazing were investigated over an annual cycle (1998) at two stations off Cudillero (central Cantabrian Sea). Mesozooplankton biomass was higher in summer/early autumn, reaching $\sim 3000 \mathrm{mg} \mathrm{dw} \mathrm{m}^{-2}$ in September. Copepods were the most abundant taxonomic group, representing 91 and $81 \%$ of the total mesozooplankton abundance in the coastal and shelf-break station respectively. Copepod gut contents were higher in summer at the coastal station, while the shelf-break station showed maximum gut contents in April. Gut contents were linearly related to integrated chlorophyll, except in the case of large animals at the shelf break station. Copepod community carbon ingestion was higher from June to September at both stations, reaching a maximum value of $\sim 165 \mathrm{mg} \mathrm{C} \mathrm{m}^{-2}$ day $^{-1}$. Calculated grazing rates translates into an average daily consumption values of $8.7 \%$ (coast) and 5.25\% (shelf-break) of total chlorophyll stock, or $20 \%$ (shelf-break) of total primary production.
\end{abstract}

Keywords: mesozooplankton, copepod, grazing, gut contents, Cantabrian Sea.

\begin{abstract}
RESUMEN: VARIACIÓN ESTACIONAL DE LA BIOMASA Y ABUNDANCIA DEL MESOZOOPLANCTON Y HERBIVORÍA DE COPÉPODOS EN el CANTÁbrico CEnTRAl (Sur del Golfo de VizCAYA). - A lo largo del año 1998, se estudió la biomasa y abundancia del mesozooplancton (en distintas fracciones de tamaño) así como la ingestión de la comunidad de copépodos en dos estaciones cercanas a Cudillero (Mar Cantábrico). La biomasa del mesozooplancton presentó sus valores más elevados en verano y a principios del otoño, alcanzando máximos de $3000 \mathrm{mg}$ Peso Seco $\mathrm{m}^{-2}$ en Septiembre. Los copépodos fueron el grupo taxonómico más abundante, representando el $91 \%$ y el $81 \%$ de la abundancia total del mesozooplancton en las estaciones de costa y talud respectivamente. El contenido estomacal de los copépodos en la estación costera fue más elevado durante el verano, mientras que en la estación situada sobre el talud, el contenido estomacal más elevado se encontró en el mes de Abril. Se encontró una relación lineal entre el contenido estomacal de los copépodos y el valor de clorofila integrado en la columna de agua, excepto en el caso de los copépodos grandes en la estación de talud. La ingestión de carbono de la comunidad de copépodos fue más elevada entre Junio y Septiembre en ambas estaciones, alcanzando valores máximos de $\sim 165 \mathrm{mg} \mathrm{C} \mathrm{m}^{-2}$ día $^{-1}$. La ingestión de la comunidad de copépodos representa un consumo diario del $8.7 \%$ (costa) y $5.25 \%$ (talud) de la clorofila total, y un $20 \%$ (talud) de la producción primaria total.
\end{abstract}

Palabras clave: mesozooplancton, copépodos, ingestión herbívora, contenido estomacal, Mar Cantábrico.

\section{INTRODUCTION}

One of the main challenges of oceanography is to improve the knowledge of the relationships between physical/biological characteristics of marine ecosystems and global change processes. In view of this, it is necessary to perform temporal studies that are extensive enough for a better understanding of the oceanic processes at a global scale. Seasonal studies in oceanography are especially important in regions where environmental conditions present a high degree of variation throughout 


\title{
Seasonal variation of mesozooplankton biomass, abundance and copepod grazing in the central Cantabrian Sea (southern B ay of B iscay)
}

\author{
IÑAKI HUSKIN ${ }^{1,2}$, EVA LÓPEZ ${ }^{1}$, LETICIA VIESCA ${ }^{1}$ and RICARDO ANADÓN ${ }^{1}$ \\ ${ }^{1}$ University of Oviedo, Dpto. BOS, c/ Catedrático Rodrigo Uría, s/n, 33071 Oviedo, Spain. \\ ${ }^{2}$ Present Address: Instituto Español de Oceanografía, C. O. de Santander, Promontorio San Martín, s/n, 39004 Santander,
} Spain.E-mail: inaki@st.ieo.es

\begin{abstract}
SUMMARY: Size fractionated mesozooplankton biomass, abundance and copepod grazing were investigated over an annual cycle (1998) at two stations off Cudillero (central Cantabrian Sea). Mesozooplankton biomass was higher in summer/early autumn, reaching $\sim 3000 \mathrm{mg} \mathrm{dw} \mathrm{m}^{-2}$ in September. Copepods were the most abundant taxonomic group, representing 91 and $81 \%$ of the total mesozooplankton abundance in the coastal and shelf-break station respectively. Copepod gut contents were higher in summer at the coastal station, while the shelf-break station showed maximum gut contents in April. Gut contents were linearly related to integrated chlorophyll, except in the case of large animals at the shelf break station. Copepod community carbon ingestion was higher from June to September at both stations, reaching a maximum value of $\sim 165 \mathrm{mg} \mathrm{C} \mathrm{m}^{-2}$ day $^{-1}$. Calculated grazing rates translates into an average daily consumption values of $8.7 \%$ (coast) and 5.25\% (shelf-break) of total chlorophyll stock, or $20 \%$ (shelf-break) of total primary production.
\end{abstract}

Keywords: mesozooplankton, copepod, grazing, gut contents, Cantabrian Sea.

\begin{abstract}
RESUMEN: VARIACIÓN ESTACIONAL DE LA BIOMASA Y ABUNDANCIA DEL MESOZOOPLANCTON Y HERBIVORÍA DE COPÉPODOS EN el CANTÁbrico CEnTRAl (Sur del Golfo de VizCAYA). - A lo largo del año 1998, se estudió la biomasa y abundancia del mesozooplancton (en distintas fracciones de tamaño) así como la ingestión de la comunidad de copépodos en dos estaciones cercanas a Cudillero (Mar Cantábrico). La biomasa del mesozooplancton presentó sus valores más elevados en verano y a principios del otoño, alcanzando máximos de $3000 \mathrm{mg}$ Peso Seco $\mathrm{m}^{-2}$ en Septiembre. Los copépodos fueron el grupo taxonómico más abundante, representando el $91 \%$ y el $81 \%$ de la abundancia total del mesozooplancton en las estaciones de costa y talud respectivamente. El contenido estomacal de los copépodos en la estación costera fue más elevado durante el verano, mientras que en la estación situada sobre el talud, el contenido estomacal más elevado se encontró en el mes de Abril. Se encontró una relación lineal entre el contenido estomacal de los copépodos y el valor de clorofila integrado en la columna de agua, excepto en el caso de los copépodos grandes en la estación de talud. La ingestión de carbono de la comunidad de copépodos fue más elevada entre Junio y Septiembre en ambas estaciones, alcanzando valores máximos de $\sim 165 \mathrm{mg} \mathrm{C} \mathrm{m}^{-2}$ día $^{-1}$. La ingestión de la comunidad de copépodos representa un consumo diario del $8.7 \%$ (costa) y $5.25 \%$ (talud) de la clorofila total, y un $20 \%$ (talud) de la producción primaria total.
\end{abstract}

Palabras clave: mesozooplancton, copépodos, ingestión herbívora, contenido estomacal, Mar Cantábrico.

\section{INTRODUCTION}

One of the main challenges of oceanography is to improve the knowledge of the relationships between physical/biological characteristics of marine ecosystems and global change processes. In view of this, it is necessary to perform temporal studies that are extensive enough for a better understanding of the oceanic processes at a global scale. Seasonal studies in oceanography are especially important in regions where environmental conditions present a high degree of variation throughout 